\title{
IDENTIFICATION OF NUMERICAL CHROMOSOME ABERRATIONS IN ARCHIVAL TUMOURS BY IN SITU HYBRIDIZATION TO ROUTINE PARAFFIN SECTIONS: EVALUATION OF 23 PHAEOCHROMOCYTOMAS
}

\author{
H. VAN DEKKEN, F. T. BOSMAN, R. TEIJGEMAN, C. J. VISSERS, T. A. TERSTEEG* , H. M. J. KERSTENS*, \\ G. P. VOOIJS* AND A. A. J. VERHOFSTAD* \\ Department of Pathology, Erasmus University Rotterdam, and ${ }^{*}$ Department of Pathology, University Hospital \\ Nijmegen, The Netherlands
}

Received 11 May 1993 Accepted 16 July 1993

\begin{abstract}
SUMMARY
We have applied non-isotopic in situ hybridization (ISH) to interphase cell nuclei of 23 phaeochromocytomas (18 primary and 5 metastatic tumours) within routine paraffin-embedded tissue sections. Each tumour was screened for numerical aberrations with a defined alphoid repetitive DNA probe set containing DNA probes specific for chromosomes 1, 7, 15, and Y. Normal adrenal medullas and other normal human cell types served as cytogenetic controls. Preservation of tissue morphology enabled targeted analysis of tumour cells. The presence of numerical chromosome changes in the tumour cells could easily be evaluated by comparing the ISH results of the DNA probes. Numerical abnormalities not previously reported in this neoplasm included overrepresentation of chromosomes 1 and 7 , loss of chromosome 15, and both gain and loss of chromosome $Y(P$ values $<0.01)$. The percentage of aneuploid cell nuclei in a tumour correlated well with the percentage of cells in the 4C peak of flow cytometric DNA histograms from these neoplasms. We conclude that interphase ISH can be used for the identification of new and reported cytogenetic changes in tumour cell nuclei within archival tissue sections. This novel procedure also allows for retrospective analysis of previously not karyotyped material.
\end{abstract}

KEY WORDS-In situ hybridization, alpha-satellite DNA probes, paraffin sections, interphase cytogenetics, phaeochromocytomas.

\section{INTRODUCTION}

The currently held views in the development of cancer have led to intensive efforts to elucidate (tumour- and/or stage-specific) chromosome aberrations in malignant diseases. At present, knowledge in this area is growing rapidly, though relatively little information is available on most non-haematological neoplasms. ${ }^{1,2}$ This is mainly due to difficulties in obtaining mitotic cells for karyotypic examination. Additional techniques

Addressee for correspondence: $H$. van Dekken, Department of Pathology, Erasmus University Rotterdam, P.O. Box 1738, 3000 DR Rotterdam, The Netherlands. using approaches applicable to interphase cells would therefore be helpful.

In the last decade, non-isotopic in situ hybridization (ISH) with (peri)centromeric chromosomespecific DNA probes has emerged as a powerful and reliable instrument for the discrimination of numerical chromosome changes in interphase cell nuclei of haematological malignancies, ${ }^{3-5}$ as well as solid tumours. ${ }^{6-11}$ This technique has also been adapted for use on tissue sections, which allows the combination of cytogenetic and histological analyses. ${ }^{12-15}$

Phaeochromocytomas are the most prevalent neoplasms of the adrenal medulla. A significant problem in this neoplasm is the unpredictability of 
its behaviour, apart from the severe hypertension which most patients suffer from. ${ }^{16}$ These tumours should be regarded as potentially malignant, but in only 10 per cent do metastases eventually develop. ${ }^{17}$ Importantly, reliable histopathological characteristics for the discrimination of phaeochromocytomas that will and those that will not metastasize have not been described. ${ }^{18}$

DNA flow cytometry of phaeochromocytomas has yielded conflicting data concerning the prognostic value of DNA aneuploidy, ${ }^{19-21}$ although in a large recent study abnormal DNA ploidy patterns were found to be unfavourable. ${ }^{22}$ Cytogenetic data on this tumour have been very limited. The only chromosomal abnormality found so far has been $a+7$ in one of three phaeochromocytomas from patients with von Hippel-Lindau syndrome. ${ }^{23}$ In sporadic tumours and as a part of MEN (multiple endocrine neoplasia) type 2, loss of heterozygosity has been detected on the tip of $1 \mathrm{p} .^{24-26}$

In this study we have applied in situ hybridization to paraffin-embedded tissue sections of 23 archival phaeochromocytomas (18 primary and 5 metastatic tumours) to search for numerical chromosome aberrations. For this purpose, a targeted set of (peri)centromeric alphoid DNA probes specific for chromosomes $1,7,15$, and $Y$ was used. The tissue architecture on the sections was adequately preserved, permitting precise location and analysis of the tumour cells. With this method, a retrospective analysis of previously not karyotyped material became feasible.

\section{MATERIALS AND METHODS}

\section{Probe and probe labelling}

In this study (peri)centromeric and repetitive satellite DNA probes specific for chromosomes 1, 7, 15, and $\mathrm{Y}$ were applied. For in situ hybridization, complete plasmid DNA was labelled with biotin-14-dATP by nick translation (BRL, Gaithersburg, MD) according to the manufacturer's directions. Probe size ranged from 50 to 500 nucleotides. The DNA probes were stored at $-20^{\circ} \mathrm{C}$.

\section{Tissue preparation}

Twenty-six paraffin-embedded archival phaeochromocytomas (1987-1991) were taken for this study: eleven specimens were from Nijmegen
University Hospital (1989-1991) and 15 came from the Erasmus University Hospital (19871991). The three archival normal adrenals (19871991) were obtained from nephrectomy specimens of patients with renal cell carcinoma. The $4 \mu \mathrm{m}$ paraffin sections were floated in warm $\left(40^{\circ} \mathrm{C}\right)$ demineralized water and mounted on aminoalkylsilane (Serva, Heidelberg, Germany)-coated glass slides. Coating of the slides was performed according to the procedure of Rentrop et l. $^{27}$ Sections were air-dried for several hours at $56^{\circ} \mathrm{C}$ in a ventilating oven.

\section{Pretreatment}

The sections were deparaffinized at room temperature in xylene $3 \times 10 \mathrm{~min}$, in ethanol $4 \times 2$ min, and immersed in 0.3 per cent $\mathrm{H}_{2} \mathrm{O}_{2}$ in methanol for $20 \mathrm{~min}$ to block endogenous peroxidase activity. The slides were then rinsed twice in phosphate-buffered saline (PBS)

Subsequently, the sections were incubated in $2 \times \mathrm{SSC}(1 \times \mathrm{SSC}=0.15 \mathrm{~mol} / 1 \mathrm{NaCl}+0.015 \mathrm{~mol} / 1$ sodium citrate) at $70^{\circ} \mathrm{C}$ for $30 \mathrm{~min}$. This incubation allows shorter pepsin digestion times and renders increased preservation of morphology. A proteolytic treatment with pepsin (Sigma, St Louis, MO; $4 \mathrm{mg} / \mathrm{ml}$ in $0 \cdot 2 \cdot \mathrm{M} \mathrm{HCl}$ ) was applied at $37^{\circ} \mathrm{C}$ (see below). The slides were then rinsed twice in distilled water and immersed in $2 \times$ SSC until denaturation.

The pepsin digestion time had been carefully evaluated for each tumour in a separate experiment by a time series $(5,10,15$, and $20 \mathrm{~min})$. The optimal pepsin time was judged by the following two criteria: ISH signal intensity and tissue morphology. In seven tumours, no adequate ISH signal was obtained within the pepsin time series. Four of these seven tumours showed an acceptable result with a longer pepsin digestion time, resulting in 23 ISH-positive tumours ( 89 per cent of all cases). The remaining three negative tumours were all 'Nijmegen' specimens from early 1989, possibly representing differences in fixation protocols in the two hospitals.

\section{In situ hybridization}

Production of single-stranded DNA for ISH was accomplished by heat denaturation. Slides were immersed for $2 \mathrm{~min}$ at $70^{\circ} \mathrm{C}$ in 70 per cent formamide. $2 \times \mathrm{SSC}$ at $\mathrm{pH} 7$. Formamide (Merck, Darmstadt, Germany) was deionized by treatment 
with a mixed-bed ion-exchange resin (Dowex AG501-X8: Bio-Rad Labs, Richmond, CA). Then the slides were dehydrated in an ethanol series [70 per cent (cold), 83 per cent, 96 percent] and air-dried at room temperature.

The chromosome-specific repetitive DNA probes were denatured for $5 \mathrm{~min}$ at $70^{\circ} \mathrm{C}$ in the hybridization mixture, which contained $1-2 \mu \mathrm{g} / \mathrm{ml}$ probe DNA, $500 \mu \mathrm{g} / \mathrm{ml}$ sonicated herring sperm DNA (Sigma), 0-1 per cent Tween-20, 10 per cent dextran sulphate, and $2 \times \mathrm{SSC}$ in 60 per cent formamide at $\mathrm{pH} 7$. After denaturation, the mixture was put immediately under a glass coverslip covering the section.

ISH was performed overnight at $37^{\circ} \mathrm{C}$ in a humidified chamber. Then the coverslips were removed by immersing the slides briefly in $2 \times$ SSC. Next the slides were washed three times for $3 \mathrm{~min}$ each in 60 per cent formamide in $2 \times \mathrm{SSC}, \mathrm{pH} 7$, at $42^{\circ} \mathrm{C}$ and subsequently two times for $5 \mathrm{~min}$ each in $2 \times \mathrm{SSC}$, pH 7 at $42^{\circ} \mathrm{C}$. The slides were then immersed in PBS +0.05 per cent Tween-p20 (PBST).

\section{Histochemistry}

For immunoperoxidase staining, the slides, in PBST, were incubated with mouse- $a$-biotin [Dakopatts, Glostrup, Denmark; 1/100 in PBS +5 per cent non-fat dry milk (PBSM)] for $30 \mathrm{~min}$ at $37^{\circ} \mathrm{C}$. They were then rinsed twice in PBST. (All subsequent washes in PBST were for $10 \mathrm{~min}$ at room temperature). An incubation with biotinlabelled horse- $a$-mouse (Vector, Burlingame, CA; $1 / 200$ in PBSM) followed for $30 \mathrm{~min}$ at $37^{\circ} \mathrm{C}$, and the slides were washed in PBST. In the meantime, the ABC complex (Vectastain Elite ABC Kit: $20 \mu \mathrm{l}$. avidin $+20 \mu \mathrm{l}$ biotin-labelled peroxidase in $1 \mathrm{ml}$ of PBSM) was prepared and complex formation was allowed for $30 \mathrm{~min}$ at room temperature. Next the ABC complex was incubated with the sections for $30 \mathrm{~min}$ at $37^{\circ} \mathrm{C}$ and non-bound complex was removed by rinsing in PBST. The probe-related signal was developed with $\mathrm{DAB}$ $\mathrm{H}_{2} \mathrm{O}_{2}(0.5 \mathrm{~g} / \mathrm{l}-0.05$ per cent, respectively, in PBS with $0.01 \mathrm{~m}$ imidazole), at neutral $\mathrm{pH}$, for $5-15 \mathrm{~min}$ at room temperature. Slides were then rinsed in distilled water for $15 \mathrm{~min}$, the signal was amplified with $\mathrm{CuSO}_{4}(0.5$ per cent in 0.9 per cent $\mathrm{NaCl})$ for $5 \mathrm{~min}$ at room temperature, and the slides were again rinsed in distilled water. Finally, the sections were counterstained with haematoxylin (10-20 $\mathrm{min})$, rinsed in tap water, dehydrated in ethanol, immersed briefly in xylene, and mounted in Permount (Fisher Scientific, Fair Lawn, NJ).

\section{Evaluation of ISH results}

The DNA probe set was analysed for each phaeochromocytoma (plus controls) on consecutive $4 \mu \mathrm{m}$ sections in a previously defined tumour area of $\pm 5 \times 5 \mathrm{~mm}$. This approach reduced artefacts due to differences in section thickness or tumour heterogeneity, respectively. For each of the probes, 100 'intact' (=spherical) and nonoverlapping $4 \mu \mathrm{m}$ nuclear slices were counted by two independent investigators and the number of solid DAB spots per nuclear fragment was scored $(0,1,2,3,4$ and $>4$ spots per nuclear slice). The individual DNA probe spot distributions were then compared and totalled. In our protocol no discrepancies emerged using these criteria. ${ }^{15}$ The numerical chromosomal aberrations were evaluated statistically by means of the KolmogorovSmirnov test. ${ }^{15,28}$ An aberrant probe spot distribution was considered to represent a numerical aberration if a $P$ value greater than 0.01 (maximum difference $>12$ per cent) was calculated.

\section{$D N A$ cytometry}

Flow cytometric DNA histograms of the paraffin-embedded tissue blocks were obtained by standard dewaxing and isolation procedures. A Facscan (Becton-Dickinson, Sunnyvale, CA) was used for measurement and analysis of propidium iodide (Sigma) stained specimens. Leukocytes were applied for calibration purposes. In the analysis, a peak with a DNA index of 1.8-2.2 was assigned $4 \mathrm{C}$.

\section{RESULTS}

A DNA probe set was selected for the screening of chromosomes $1,7,15$, and $Y$. In 23 phaeochromocytomas (18 primary and 5 metastatic tumours) taken from 21 patients (11 male and 10 female; mean age 41.0 years; Table I), high-quality in situ hybridization (ISH) was obtained that was suitable for subsequent interphase analysis. DNA probes for chromosomes 1, 7, and $\mathrm{Y}$ were chosen since numerical aberrations of these chromosomes are frequently observed in solid tumours. Furthermore, we have previously seen monosomy 15 (and loss of the $\mathrm{Y}$ chromosome) in predominantly 
Table I — Twenty-three phaeochromocytomas: tumour/patient features

\begin{tabular}{|c|c|c|c|}
\hline $\begin{array}{l}\text { Tumour } \\
\text { No. }\end{array}$ & Sex/age years & Tumour site & Occurrence* \\
\hline 1 & $\mathrm{M} / 56$ & Adrenal/primary & Unknown \\
\hline 2 & $\mathrm{M} / 59$ & Adrenal/primary & Sporadic \\
\hline 3 & $\mathrm{M} / 25$ & Adrenal/primary & NF \\
\hline 4 & $\mathrm{M} / 43$ & Adrenal/primary & Sporadic \\
\hline 5 & $\mathrm{~F} / 45$ & Adrenal/primary & Sporadic \\
\hline 6 & $\mathrm{M} / 9$ & Adrenal/primary & Unknown \\
\hline 7 & $F / 35$ & Thorax/metastasis & Sporadic \\
\hline 8 & $F / 36$ & Kidney/metastasis & Sporadic \\
\hline 9 & $\mathrm{~F} / 53$ & Adrenal/primary & Sporadic \\
\hline 10 & $F / 44$ & Adrenal/primary & Sporadic \\
\hline 11 & $\mathrm{M} / 63$ & Adrenal/primary & Sporadic \\
\hline 12 & $\mathrm{~F} / 50$ & Bladder/primary & Sporadic \\
\hline 13 & $\mathrm{M} / 41$ & Adrenal/primary & Sporadic \\
\hline 14 & $\mathrm{M} / 40$ & Adrenal/primary & Sporadic \\
\hline 15 & $\mathrm{M} / 28$ & Adrenal/primary & Sporadic \\
\hline 16 & $\mathrm{M} / 65$ & Adrenal/primary & Sporadic \\
\hline 17 & $\mathrm{~F} / 47$ & Adrenal/metastasis $\dagger$ & MEN2 \\
\hline 18 & $\mathrm{~F} / 60$ & Adrenal/primary & Sporadic \\
\hline 19 & $\mathrm{M} / 25$ & Lymph node/metastasis & Sporadic \\
\hline 20 & $\mathrm{M} / 25$ & Adrenal/primary & Sporadic \\
\hline 21 & $\mathrm{~F} / 26$ & Adrenal/primary & Sporadic \\
\hline 22 & $\mathrm{~F} / 30$ & Adrenal/primary & NF \\
\hline 23 & $\mathrm{~F} / 37$ & Thorax/metastasis & Sporadic \\
\hline
\end{tabular}

*Sporadic or related to hereditary diseases: multiple endocrine neoplasia type 2 (MEN2), von Hippel-Lindau syndrome (VHL), von Recklinghausen's neurofibromatosis (NF). In the case of metastasis or recurrence, the original tumour is referred to.

$\dagger$ Recurrence of the tumour.

†Metastasis of tumour 20 .

Recurrence of tumour 7.

high-stage and grade bladder tumours. ${ }^{29}$ For that reason the chromosome 15 DNA probe was included. In order to evaluate the ISH results of the tumours, control experiments were performed on normal adrenal medullas (three cases, mean age 60.0 years). Normal stromal cells in the specimens, if present, were utilized as internal (diploid) controls.

In nine control tissues, ISH showed low percentages of hyperdiploid cell nuclei ( $<5$ per cent). In this respect, a difference was observed between leukocyte (four cases: mean value 0.5 per cent) and adrenal cortex controls (four cases: mean value 2.7 per cent). Leukocyte nuclei showed a diploid distribution (Figs 1A, 1B, and 2A), while 1SH with the DNA probe set to three normal adrenal medullas revealed the existence of hyperdiploid cell nuclei for all probes (range 8-20 per cent; see also Figs $1 \mathrm{C}$ and 2B). Diploid ISH patterns without hyperdiploid nuclei were also seen in normal kidney, prostrate, and gastric specimens (not shown). Therefore, the presence of 5-25 per cent hyperdiploid cells in the ISH distribution pattern of a phaeochromocytoma was regarded as normal ('euploid'). Using this definition, a euploid ISH pattern was observed in 15 phaeochromocytomas and an aneuploid distribution in 8 (Table II; Figs $2 \mathrm{C}$ and $2 \mathrm{D}$ ).

The ISH results of the 23 phaeochromocytomas are summarized in Table II. Six tumours carrying a numerical aberration were observed. The aberrant DNA probe distributions were evaluated statistically by the Kolmogorov-Smirnov test $(P<0.01$ values; see also Fig. 3). In a metastatic phaeochromocytoma (tumour 8), loss of chromosome 15 was seen (Fig. 3C). Lower numbers of \#15 ISH spots per nucleus can be seen than, for example, of \#7 (Figs 4A and 4B). Fibroblasts present in this 

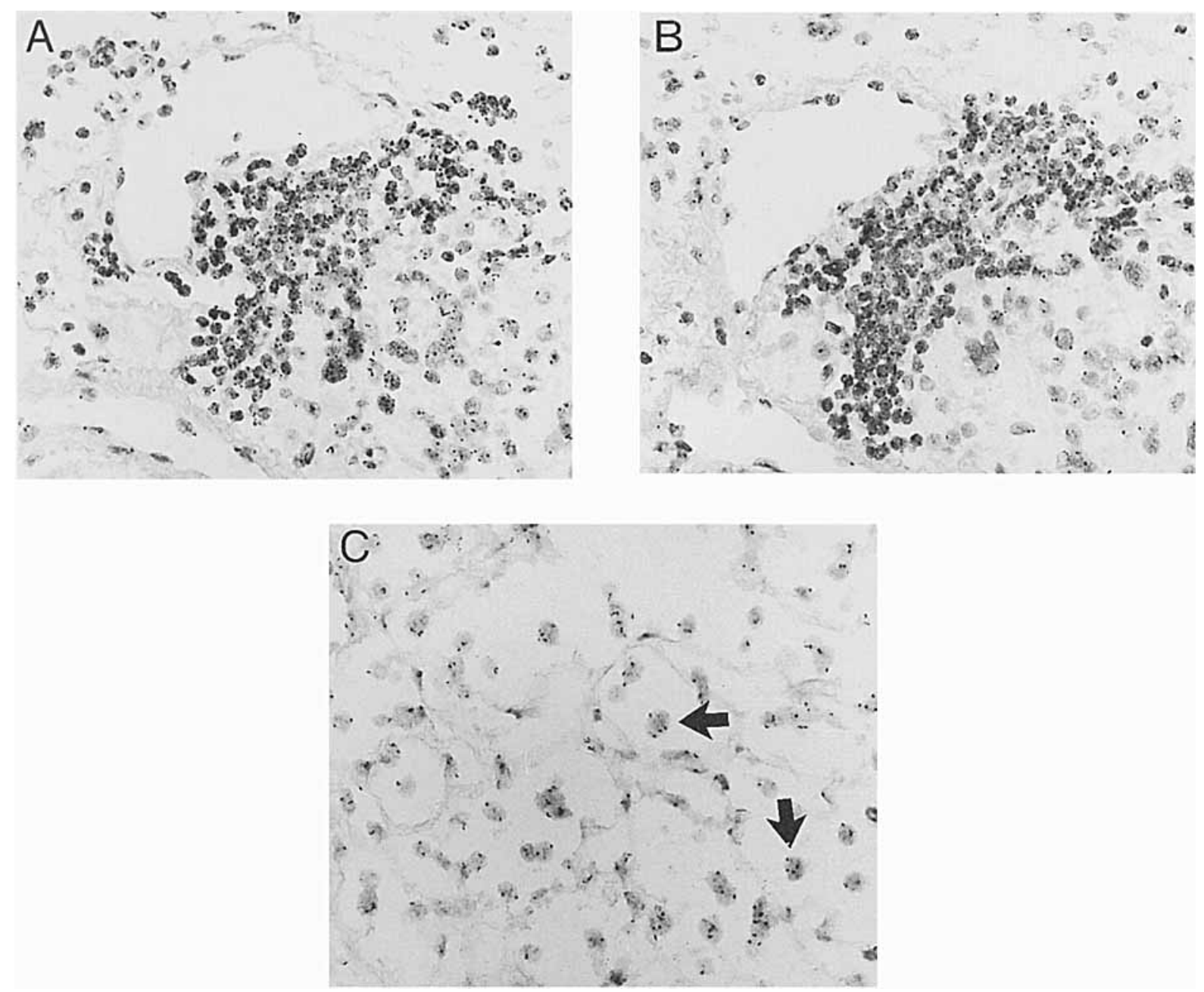

Fig. 1-(A) In situ hybridization (ISH) with the chromosome 1-specific DNA probe to a leukocytic infiltrate within $4 \mu \mathrm{m}$ sections of tumour 2. The ISH-related spots were visualized with immunoperoxidase/DAB (black); hacmatoxylin was used as a counterstain (grey). No hyperdiploid leukocytes can be distinguished. (B) Same as A, chromosome Y DNA probe. Note the haploid hybridization pattern when compared with the chromosome 1 DNA probe. (C) ISH with the chromosome 7-specific probe to a normal adrenal. Hyperdiploid nuclei can be discriminated in the normal adrenal medulla (arrows)

specimen revealed a diploid ISH distribution. Tumour 15 showed an increase of ISH spots for chromosome 7 when compared with the other probes (Fig. 3D). On average, these nuclei contained more spots for the \#7 probe than, for example, for \#1 (Figs 4C and 4D). Loss of the $Y$ chromosome was seen in tumours 3 (Fig. 4B) and 14. This Y-loss is restricted to the tumour cells (Fig. 4E). Overrepresentation of chromosomes 1 and $\mathrm{Y}$ was observed in phaeochromocytomas 13 and 2 (Fig. 3A). In the latter patient, the normal haploid $Y$ pattern was seen in leukocytes present in the same specimen (Figs 1A and 1B). Polymor- phism of chromosome 15 repetitive DNA was found in tumour 16 by comparing the probe histograms of the tumour cells with the cortical (and leukocyte) control cells present in this specimen (Figs 3E and 3F). A high number of nuclei with only one ISH spot were observed for the \#15 probe (Fig. 4F).

The percentages of hyperdiploid nuclei (more than 2 ISH spots) correlated well with the cytometric DNA histograms, especially when ISH criteria for tumour ploidy were used (Table II and Discussion). No relationship between tumour site and ISH ploidy or aberrations was observed. Further, 

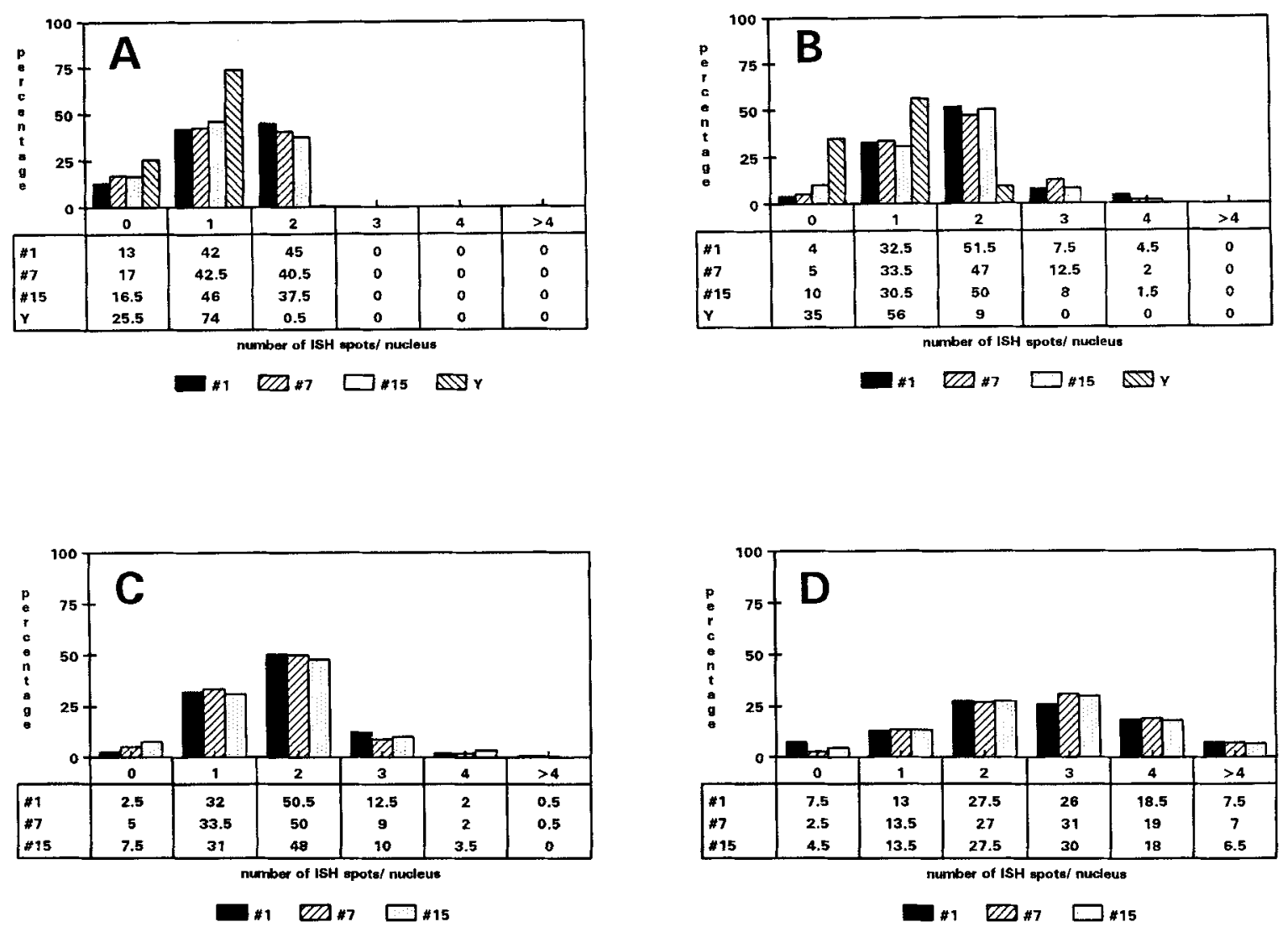

Fig. 2-DNA probe frequency distributions (with tables) of the number of hybridization spots per nucleus for control and phaeochromocytoma specimens after ISH with the probe sets to $4 \mu \mathrm{m}$ tissue sections. For all of the probes, 100 spherical and non-overlapping nuclei were counted by two independent investigators. The results were added and plotted as a percentage per probe. (A) Leukocytes (in tumour 2) showing the diploid ISH profile. (B) Normal adrenal medulla (Fig. 1C), demonstrating the tissue-specific euploid pattern. (C) Patient 22, showing a distribution pattern which is comparable to those in normal adrenal medullas, without numerical chromosome changes. (D) Patient 5. An aneuploid pattern with many hyperdiploid cells is seen

no correlation was found between the occurrence of the disease and the ISH results. This could, however, be due to the low number of hereditary diseases in this study.

\section{DISCUSSION}

Non-isotopic in situ hybridization with chromosome-specific DNA probes to paraffinembedded archival tissue sections allowed us to screen 23 phaeochromocytomas for the presence of numerical changes of selected chromosomes. Despite the sectioning artefact, which yields sliced nuclei, specific chromosome aberrations were detected and evaluated statistically. The tissue architecture was sufficiently retained, enabling histological examination and precise location of tumour cells. Thus, non-tumour cells, such as fibroblasts, blood cells, and other normal tissue components, could be excluded from analysis. This is an advantage over techniques using isolated cells or tissue extracts. Moreover, the normal stromal cells can be used for control purposes with respect to hybridization efficiency and patient genetics. This is exemplified in tumour 16 , containing a polymorphism for alphasatellite 15 DNA. This polymorphism would otherwise have been interpreted as a loss of chromosome 15. Finally, ISH to archival material renders the possibility of targeted retrospective cytogenetic analysis, e.g., on cells that were not, or could not be, inspected by conventional cytogenetic procedures. 
Table II - Cytogenetics and ploidy patterns of 23 phaeochromocytomas by ISH to $4 \mu \mathrm{m}$ sections with a panel of chromosome-specific repetitive DNA probes $(1,7,15$, and $\mathrm{Y}$ ) and DNA flow cytometry

\begin{tabular}{|c|c|c|c|}
\hline $\begin{array}{l}\text { Tumour } \\
\text { No. }\end{array}$ & Cytometry* & Aneuploidy $\dagger$ & Aberrations \\
\hline 1 & Tetraploid & 29 & \\
\hline 2 & Tetraploid & 15 & $+\mathrm{Y}$ \\
\hline 3 & Diploid & 22 & $-\mathrm{Y}$ \\
\hline 4 & Tetraploid & 26 & \\
\hline 5 & Tetraploid & 53 & \\
\hline 6 & Diploid & 22 & \\
\hline 7 & Diploid & 14 & \\
\hline 8 & Tetraploid\$ & 47 & -15 \\
\hline 9 & Tetraploid & 15 & \\
\hline 10 & Tetraploid & 36 & \\
\hline 11 & Aneuploid & 21 & \\
\hline 12 & Diploid & 6 & \\
\hline 13 & Tetraploid & 47 & +1 \\
\hline 14 & Tetraploid & 13 & $-\mathrm{Y}$ \\
\hline 15 & Diploid & 17 & +7 \\
\hline 16 & Tetraploid & 23 & $(15) \|$ \\
\hline 17 & Tetraploid & 6 & \\
\hline 18 & Tetraploid & 19 & \\
\hline 19 & Aneuploid & 39 & \\
\hline 20 & Aneuploid & 40 & \\
\hline 21 & Diploid & 18 & \\
\hline 22 & Tetraploid & 13 & \\
\hline 23 & Tetraploid & 9 & \\
\hline
\end{tabular}

*Ploidy of the tumour, according to Nativ et al..22 diploid $=\leq 15$ per cent cells in the $4 C$ peak; tetraploid $=>15$ per cent cells in the $4 \mathrm{C}$ peak; aneuploid denotes the presence of a third peak other than 2 or $4 \mathrm{C}$.

$\dagger$ Percentage of cells with more than two hybridization spots. IKolmogorov-Smirnov test: $p<0.01$.

§Image cytometry on another tissue block of the same tumour. liTumour and control cells of this patient showed strong poiymorphism for alpha-satellite 15 DNA.

The ISH hyperdiploid nuclei (three or four spots) in the normal adrenal medullas are likely to be tetraploid cells (and not $\mathrm{G}_{2} \mathrm{M}$ ). An ISH-G $\mathrm{G}_{2} \mathrm{M}$ cell shows an increase in spot size, but not doubling of spots, after hybridization with (peri)centromeric DNA probes. ${ }^{8,30}$ Further, if doubling should occur, these spots should appear as a pair, not located far apart (e.g., Fig. 1C). Tetraploid populations in DNA histograms of normal adrenal glands were also observed by other investigators. ${ }^{19,20}$ In a recent study on phaeochromocytomas, an upper limit as high as 15 per cent was regarded as normal for the percentage of nuclei found in the $4 \mathrm{C}$ peak of normal adrenals. ${ }^{22} \mathrm{We}$ therefore conclude that the hyperdiploid cells seen by us in normal adrenal medulla reflect a tetraploid DNA content. This replication phenomenon is also found in other normal tissues, e.g., the liver.

A fair correlation was found between the percentage of ISH hyperdiploid cells and the amount of cells in the $4 \mathrm{C}$ peak of the flow cytometric DNA histograms of the phaeochromocytomas (Table II). If we use the ISH criteria for ploidy (diploid, euploid and aneuploid $=<5$ per cent, $5-25$ per cent, and $>25$ per cent hyperdiploid cells) on both DNA cytometric and ISH data, a good correlation is found in ploidy definition. Then a disagreement on ploidy pattern appears in only $4 / 23$ cases. It can thus be speculated that phaeochromocytomas contain low percentages of (diploid) $G_{2} M$ cells, since the latter are not discriminated by ISH. ${ }^{8,30}$ We did not see a correlation between ploidy and tumour progression (primary, metastatic). Such a correlation appeared inconsistent in several DNA cytometric studies. ${ }^{19-21}$ The existence of tetraploid populations in normal adrenal medulla might be related to this controversy.

An overrepresentation of chromosome 7 was found in a primary tumour (Table II). This might have prognostic significance. It has been suggested that bladder cancers with +7 show more aggressive biological behaviour. ${ }^{31}$ In support of this was the correlation found between chromosome 7 copy number, determined by ISH, and bladder tumour grade, stage, and proliferation index. ${ }^{11}$ An underrepresentation of chromosome 15 was detected in a metastatic phaeochromocytoma. It could indicate a late cytogenetic event during tumour progression. Previously, loss of chromosome 15 was observed by us in high-stage and grade bladder tumours. ${ }^{29}$ Loss of chromosome 15 was also found in non-seminoma germ cell tumours, when compared with seminomas. ${ }^{32}$ These authors advocated a model in which seminomas were regarded as preceding the more pathogenic non-seminomas. Y-chromosome aberrations, mostly losses, can be seen in many solid tumours. In our study we could demonstrate that this event is restricted to the tumour cells.

We can speculate on the nature of the numerical changes found by calculating the total number of ISH spots in all 200 cells counted for a DNA probe with an aberrant distribution (Fig. 3) relative to the mean value of the other autosomal probes in the same tumour. For tumour 15, this probe value (\#7/mean of $\# 1+\# 15$ ) would be $1 \cdot 42$. This suggests that the chromosome 7 overrepresentation in 

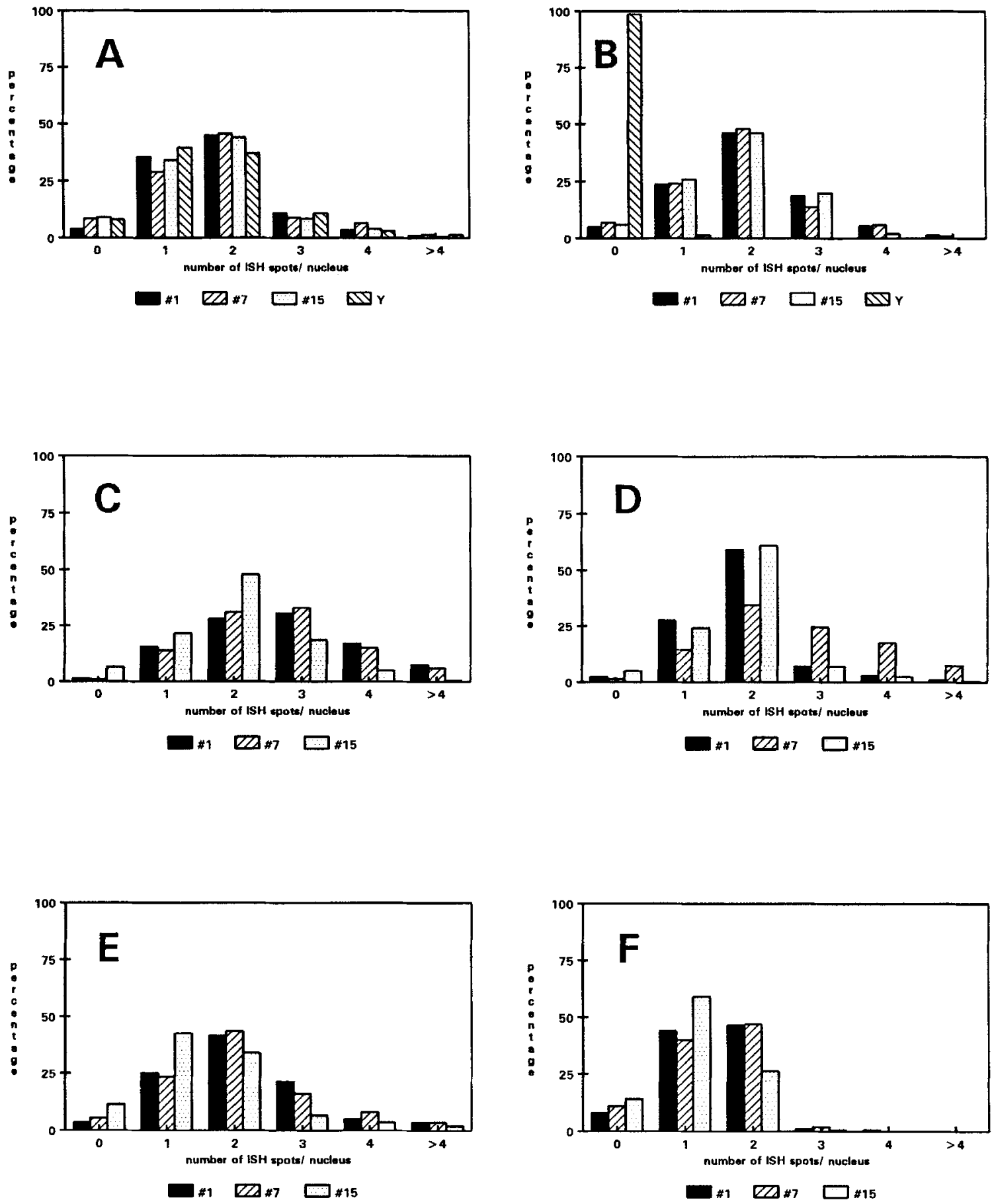

Fig. 3-DNA probe frequency distributions (without tables) of the number of hybridization spots per nucleus for abnormal phaeochromocytoma specimens after ISH with the probe sets to $4 \mu \mathrm{m}$ tissue sections. (A) Tumour 2 , containing an extra copy of the Y chromosome. The Y profile follows the autosomal distribution. (B) Loss of chromosome Y in tumour 3. (C) Specimen 8: loss of chromosome 15, demonstrated by a shift to the left (as compared with the other DNA probes) of the \#15 distribution. (D) Overrepresentation of \#7 in tumour 15. The 7 profile is shifted to the right. (E) A shift to the left of the \#15 profile in tumour 16. (F) Same specimen, adrenal cortex control. The same pattern is seen, indicating polymorphism of chromosome 15 alpha-satellite DNA 

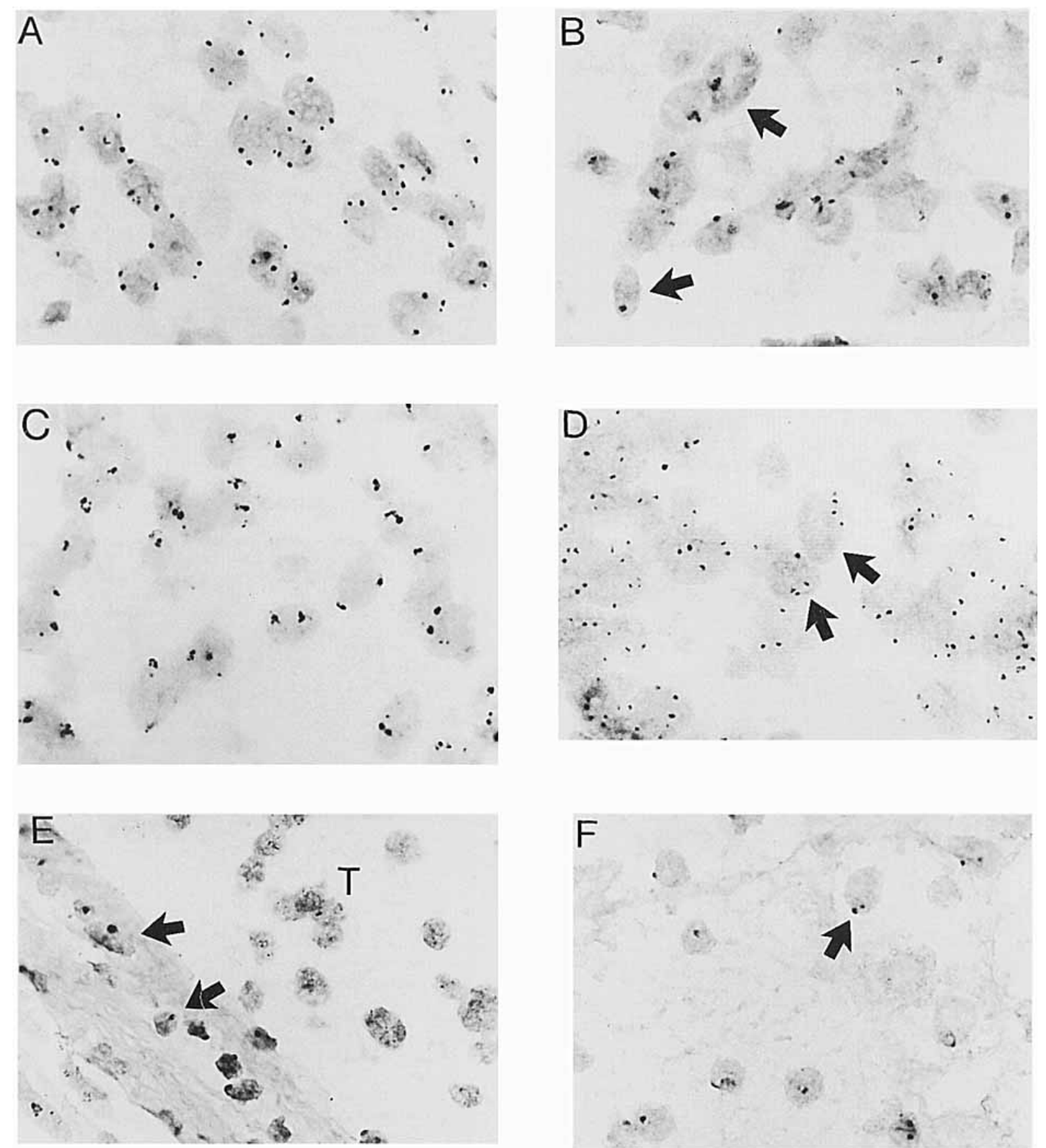

Fig. 4-ISH with the chromosome 7-specific DNA probe to the (metastatic) tumour 8 . An aneuploid pattern with many hyperdiploid nuclei is seen. (B) Loss of chromosome 15 in the same tumour. Two nuclei with only one spot are arrowed. (C) \#1-ISH to specimen 15. Many nuclei carry two spots. (D) ISH to the same tumour with the \#7 DNA probe. Note that the mean number of spots per nucleus is higher than in C. Many nuclei containing three or four spots can be seen (two are arrowed), indicating a gain of chromosome 7. (E) ISH with the Y-specific probe to the phaeochromocytoma of tumour 3. Chromosome $\mathrm{Y}$ is absent in tumour cell nuclei (T), but present in stromal cells (arrows). (F) Adrenal cortex control, confirmed by absence of chromogranin A staining, in specimen 16. Many nuclei contain only one spot, whereas some display a large and a small signal denoting chromosome 15 polymorphism (arrow) 
this neoplasm was caused by a trisomy. $Y$ values in normal adrenals and control cells range from $0 \cdot 4$ to $0 \cdot 6$, being roughly in accordance with $\mathrm{Y}$ haploidy. The chromosome 1 over- and chromosome 15 underrepresentation in phaeochromocytomas 13 and 8 have values of $1 \cdot 19$ and $0 \cdot 75$, respectively. These numbers are probably biased by cytogenetic heterogeneity in these very aneuploid tumours (Table II).

In this investigation, we focused on the detection of numerical chromosome changes. Aberrations of chromosomes $1,7,15$, and $\mathrm{Y}$ were disclosed in a tumour that is marked by an almost complete absence of karyotypic information. ${ }^{23}$ However, many (early) genetic events in oncogenesis and progression are of a structural kind, e.g., loss of the tip of $1 \mathrm{p}$ in phaeochromocytomas. ${ }^{26}$ Preliminary ISH experiments on archival phaeochromocytomas demonstrated the feasibility of detecting unique regional DNA probes (e.g., for the relevant 1 p36 band) in the paraffin-embedded sections (Tersteeg and van Dekken, unpublished observations).

\section{ACKNOWLEDGEMENTS}

We wish to thank Dr P. de Wilde and Dr E. van 't Hoff for statistical advice. H. Beck and W. Lange are acknowledged for preparing some of the 'Nijmegen' tumour DNA histograms. We also thank Drs A. Hermus and S. Lamberts for providing patient data (Department of Endocrinology, Nijmegen and Rotterdam, respectively); Drs H. Cook (MRC, Edinburgh, U.K.), H. F. Willard (Stanford University, Stanford, CA, U.S.A.), and B. N. White (Queen's University, Kingston, Canada) for providing us with the alphoid DNA probes; and Dr A. El-Naggar (MDACC, Houston, TX, U.S.A.) for supplying the normal adrenal specimens.

\section{REFERENCES}

1. Dal Cin P, Sandberg AA. Chromosomal aspects of human oncogenesis. Crit Rev Oncogenesis 1989; 1: 113-126.

2. Solomon E, Borrow J, Goddard AD. Chromosome aberrations and cancer. Science 1991; 254: 1153-1160.

3. Van Dekken H, Bauman JGJ. A new application of in situ hybridization: detection of numerical and structural chromosome aberrations with a combination centromeric-teleomeric DNA probe. Cutogenet Cell Genet 1988; 48: 188-189.

4. Anastasi J, Le Beau MM, Vardiman JW, Westbrook CA. Detection of numerical chromosomal abnormalities in neoplastic hematopoietic cells by in situ hybridization with a chromosome-specific probe. Am J Pathol 1990; 136: 131-139.
5. Poddighe PJ, Moesker O, Smeets D, Award BH, Ramaekers FCS, Hopman AHN. Interphase cytogenetics of hematological cancer: comparison of classical karyotyping and in situ hybridization using a panel of eleven chromosome specific DNA probes. Cancer Res 1991; 51: 1959-1967.

6. Cremer T, Tesin D, Hopman AHN, Manuelidis L. Rapid interphase and metaphase assessment of specific chromosomal changes in neuroectodermal tumor cells by in situ hybridization with chemically modified DNA probes. Exp Cell Res 1988; 176: 199-220.

7. Van Dekken H, Pizzolo JG, Kelsen DP, Melamed MR. Targeted cytogenetic analysis of gastric tumors by in situ hybridization with a set of chromosome specific DNA probes. Cancer 1990; 66: 491-497.

8. Van Dekken H, Pizzolo JG, Reuter VE, Melamed MR. Cytogenetic analysis of human solid tumors by in situ hybridization with a set of 12 chromosome specific DNA probes. Cytogenet Cell Genet 1990; 54: $103-107$.

9. Arnoldus EPJ, Noordermeer IA, Peters ACB, et al. Interphase cytogenetics of brain tumors. Genes Chrom Cancer 1991; 3: 101-107.

10. Hopman AHN, Moesker O, Smeets AWGB, Pauwels RPE, Vooijs GP, Ramaekers FCS. Numerical chromosome 1, 7, 9, and 11 aberrations in bladder cancer detected by in situ hybridization. Cancer Res 1991; 51: 644-651.

11. Waldman FM, Carroll PR, Kerschmann R, Cohen MB, Field FG, Mayall $\mathrm{BH}$. Centromeric copy number of chromosome 7 is strongly correlated with tumor grade and labeling index in human bladder cancer. Cancer Res 1991; 51: 3807-3813.

12. Burns J, Redfern DRM, Esiri MM, McGee JO'D. Human and viral gene detection in routine paraffin embedded tissue by in silu hybridisation with biotinylated probes: viral localisation in herpes encephalitis, J Clin Pathol 1986; 39: 1066-1073.

13. Pringle JH, Homer CE, Warford A, Kendall CH, Lauder I. In situ hybridization: alkaline phosphatase visualization of biotinylated probes in cryostat and paraffin sections. Histochem $J$ 1987; 19: $488-496$.

14. Emmerich $\mathrm{P}$, Jauch $\mathrm{A}$, Hofmann $\mathrm{M}-\mathrm{C}$, Cremer $\mathrm{T}$, Wait $\mathrm{H}$. Interphase cytogenetics in paraffin embedded sections from human testicular germ cell tumor xenografts and in corresponding cultured cells. Lab Invest 1989; 61: 235-242.

15. Van Dekken H, Kerstens HMJ, Tersteeg TA, Verhofstad AAJ, Vooijs GP. Histological preservation after in situ hybridization to archival solid tumour sections allows discrimination of cells bearing numerical chromosome changes. J Pathol 1992; 168: 317-324.

16. Lightman $\mathrm{S}$. Adrenal medulla. In: James VHT, ed. Comprehensive Endocrinology: The Adrenal Gland. New York: Raven Press, 1979; 283-307.

17. Scott HW Jr, Halter SA. Oncologic aspects of pheochromocytoma: the importance of follow-up. Surgery 1984; 96: 1061-1066.

18. Neville AM, O'Hare MJ. Aspects of structure, function, and pathology. In: James VHT, ed. Comprehensive Endocrinology: The Adrenal Gland. New York: Raven Press, 1979; 1-65.

19. Klein FA, Kay S, Ratliff JE, White FKH, Newsome HH. Flow cytometric determinations of ploidy and proliferation patterns of adrenal neoplasms: an adjunct to histological classification. $J$ Urol 1985; 134: 862-866.

20. Hosaka Y, Rainwater LM, Grant CS, Farrow GM, van Heerden JA, Lieber MM. Pheochromocytoma: nuclear deoxyribonucleic acid patterns studied by flow cytometry. Surgery 1986; 100: 10031008

21. Amberson JB, Vaughan ED, Gray GF, Naus GJ. Flow cytometric determination of nuclear DNA content in benign adrenal pheochromocytomas. Urology 1987; 30: 102-104.

22. Nativ O, Grant CS, Sheps SG, et al. The clinical significance of nuclear DNA ploidy pattern in 184 patients with pheochromocytoma. Cancer 1992; 69: 2683-2687.

23. Sandberg AA. The Chromosomes in Human Cancer and Leukemia. 2nd edn. New York: Elsevier, 1990: 894-895.

24. Mathew CGP, Smith BA. Thorpe K, et al. Deletion of genes on chromosome 1 in endocrine neoplasia. Nature 1987; 328: 524-526.

25. Khosla S, Patel VM, Hay ID, et al. Loss of heterozygosity suggests multiple genetic alterations in pheochromocytomas and medullary thyroid carcinomas. J Clin Invest 1991; 87: 1691-1699. 
26. Moley JF, Brother MB, Fong C-T, et al. Consistent association of lp loss of heterozygosity with pheochromocytomas from patients with multiple endocrine neoplasia type 2 syndromes. Cancer Res 1992; 52: 770-774.

27. Rentrop M, Knapp B, Winter H, Schweizer J. Aminoalkylsilanetreated glass slides as support for in situ hybridization of keratin cDNAs to frozen tissue sections under varying fixation and pretreatment conditons. Histochem J 1986; 18: 271-276.

28. Young IT. Proof without prejudice: use of the KolmogorovSmirnov test for the analysis of histograms from flow systems and other sources. J. Histochem Cytochem 1977; 25: 935-941.
29. Schervish E, Melamed MR, van Dekken $\mathrm{H}$, et al. Manuscript in preparation.

30. Beck JLM, Hopman AHN, Vooijs GP, Ramaekers FCS. Chromosome detection by in situ hybridization in cancer cell populations which were flow cytometrically sorted after immunolabeling. Cytometry 1992; 13: 346-355.

31. Sandberg AA. Chromosome changes in bladder cancer: clinical and other correlations. Cancer Genet Cytogenet 1986; 19: 163-175.

32. De Jong B, Oosterhuis JW, Castedo SMMJ, Vos A, te Meerman GJ. Pathogenesis of adult testicular germ cell tumors. Cancer Genet Cytogenet 1990; 48: 143-167. 